\title{
Innovative Industrial Use of Bamboo as Key “Green" Material
}

\author{
Piotr F. Borowski ${ }^{1, *(1)}$, Iaroslav Patuk ${ }^{2}$ (i) and Erick R. Bandala ${ }^{3}$ (i) \\ 1 Institute of Mechanical Engineering, Warsaw University of Life Sciences, 166 Nowousynowska Str., \\ 02-787 Warsaw, Poland \\ 2 Research and Development Center, Next Meats Co., Ltd., Nagaoka 940-2127, Japan; patuk@nextmeats.co.jp \\ 3 Division of Hydrologic Sciences, Desert Research Institute, 755 E. Flamingo Road, Las Vegas, NV 89119, USA; \\ erick.bandala@dri.edu \\ * Correspondence: piotr_borowski@sggw.edu.pl
}

Citation: Borowski, P.F.; Patuk, I.; Bandala, E.R. Innovative Industrial Use of Bamboo as Key "Green" Material. Sustainability 2022, 14, 1955. https://doi.org/10.3390/su14041955

Academic Editors: Andrea Colantoni, Enrico Maria Mosconi, Marco Marconi, Donato Morea and Mattia Mattia Pellegrini

Received: 17 January 2022

Accepted: 2 February 2022

Published: 9 February 2022

Publisher's Note: MDPI stays neutral with regard to jurisdictional claims in published maps and institutional affiliations.

Copyright: () 2022 by the authors Licensee MDPI, Basel, Switzerland. This article is an open access article distributed under the terms and conditions of the Creative Commons Attribution (CC BY) license (https:// creativecommons.org/licenses/by/ $4.0 /)$.

\begin{abstract}
This study investigates the use of bamboo in different industrial sectors, including construction and energy, to highlight its mechanical properties, resources, and innovative use through information gathered from Ethiopia, Guinea, and Georgia (Caucasus) as study cases. Research shows that bamboo is a common plant and an easily accessible material possessing remarkable characteristics for different applications in different countries. The main goal of this study is to highlight the properties of bamboo that make it an interesting material with applications in several economic branches as a green material positively influencing the environment. The results of this study show a utilitarian use of bamboo in industries where production is based on bamboo or bamboo-related materials and wide possibilities for using bamboo in innovative and creative ways. Bamboo's mechanical and physicochemical properties are discussed as well as its potential as a raw material for use in composites or for the production and processing of semi-finished products and parts of end devices, all with a view to its positive environmental impact.
\end{abstract}

Keywords: bamboo; materials; mechanical properties; mechanical engineering; climate; Industry 4.0; innovation; energy

\section{Introduction}

Industrial and service development has led researchers to focus on non-conventional materials with significant roles in innovation development and implementation [1]. Entrepreneurs aim to develop innovative and creative strategies using good, valuable, durable, and sustainable materials that serve industrial and economic development [2,3]. As result, the use of natural construction and production materials has increased interest related to the desire of developing greener and/or environmentally friendly processes [4]. Several natural, re-emerging materials used in the past (e.g., bamboo, straw, reeds, and hemp) have been found useful again and deserving of research to fully understand their potential for different applications.

From the different materials available, bamboo-a group of perennial grass with large woody culm encompassing 1662 species with 121 genera-has increasingly attracted attention as an interesting material, including single bamboo fibres and bamboo strips, to replace conventional construction and other materials [5]. Bamboo products have been suggested as having a significant positive environmental impact and distinctive social and economic benefits [6] by calling for innovative approaches to using natural materials, triggering eco-innovation, and promoting the circular economy [7]. The use of bamboo requires creativity and reopening to natural materials, which have been proposed as foundational to the economy of the future as they reflect the changes taking place due to innovative ideas and solutions as well as successive industrial evolution and technological progress $[8,9]$. 
Expanding the diverse use of bamboo as an ecological material makes sense because more than 1000 varieties of bamboo are distributed around the world in tropical, subtropical, and temperate regions [10]. Additionally, the bamboo growth cycle (3 5 years) is significantly shorter than that of wood, its carbon capture ability is three-fold better compared to other plants (3.73 cubic meter of $\mathrm{CO}_{2}$ ) [11], and it possess outstanding mechanical properties. For example, bamboo's tensile strength is $370 \mathrm{MPa}$ and its elastic modulus is $20,000 \mathrm{MPa}$, comparable or higher than the values reported for some types of steel, wood, or concrete [12].

As the world looks for ecological solutions, bamboo is one of the most economical forest species, with new uses found every few years. Just to mention one example, recent antibacterial and UV absorption bamboo clothing was created using a characteristic of lignin in bamboo fibre [11]. Nowadays, bamboo plays a key role in economic development, and it certainly can cover a wide range of human needs, from environmental protection to use in home appliances.

As defined by the Sustainable Development Goals (SDGs) proposed by the United Nations, promoting and supporting actions towards sustainable development, including product design, development, and withdrawal, will help to enhance product life cycle [13] and simultaneously increase efficiency, competitiveness, and innovation [1].

The aim of this study was to analyse different applications of bamboo in various sectors of the economy by considering its numerous properties and to practically demonstrate the innovative use of bamboo in the construction, textile, gardening, landscape architecture, and energy sectors as a green material.

\section{Materials and Methods}

This research used mixed methods applied to receive answers to the following questions: how, why (qualitative), and how much (quantitative). The research was conducted by collecting information in selected countries that use bamboo for different industrial production processes (Ethiopia, Georgia, Guinea). The information was collected during local interviews and discussions with habitants in semi-structured surveys as well as from the authors' own observations (qualitative methods). Interviews in Ethiopia were conducted in the Huruta village near Assela and in the Gulele subcity of Addis Ababa. In Guinea the interviews were carried out in Kindia, Matam and Kiroli-both places are suburbs of Conakry. In these two countries, bamboo is widely used in construction, heating and in the household. In Ethiopia, bamboo is widely used for pole, rod, and stake production, but also in the construction sector for roofing, scaffolding, depots, and platforms. In Georgia, survey information was collected in Batumi, where bamboo is primarily used for everyday products. The respondents were asked to explore and discuss the bamboo topic in small groups (4-6 people), where they openly shared opinions and were allowed to explain their point of view. The discussion was moderated according to rules for the focus group. During the semi-structured interview, specific questions related to bamboo were asked, while additional unplanned questions were also included. The collected information was used for a secondary analysis consisting of desk research on the mechanical and chemical properties of bamboo from the specialized literature. The data collected made it possible to analyse the behaviour of different industries and to perform a descriptive analysis of sectors dealing with bamboo-based production (qualitative methods).

\section{Results}

\subsection{Bamboo Plant Characteristics}

Bamboo is perennial, green year-round, and part of the grass family plant. Like grass, bamboo is characterized by a jointed stem called a culm. Typically, culms are blanked, but some bamboo species have solid culms [14]. The splitting force along the grain of the bamboo internode is low; however, thanks to the existence of nodes, interlayer propagation becomes more difficult [15]. There are several different characteristics (e.g., strength, smoothness, straightness, lightness, hardness, and hollowness of culms, the regularity 
and facility with which they split, and different lengths, sizes, and thicknesses of their joints) that make bamboo suitable for numerous "end products" and different purposes. Each culm segment begins and ends with a reliable joint called the node. Bamboo nodes have a positive effect on properties, increasing their strength [16]. Nodes are typified by a bulging encircling the ends of the culm segments. Bamboo biomass increases $10 \%$ to $30 \%$ per year, significantly more than the biomass increase for trees $(2-5 \%)$, which suggests a preferable performance of the raw material for use. Almost every species of bamboo spreads very quickly and possesses an aggressive root system in the form of rhizomes spreading in the soil. In addition, many bamboo varieties are cold-resistant and capable of growth under freezing conditions (minus $15-20^{\circ} \mathrm{C}$ ); for these reasons, bamboo species occupy over 50 million hectares of land $[17,18]$. Because of its fast growth cycle (Figure 1), cultivation of bamboo is considered an interesting climate change mitigation strategy.

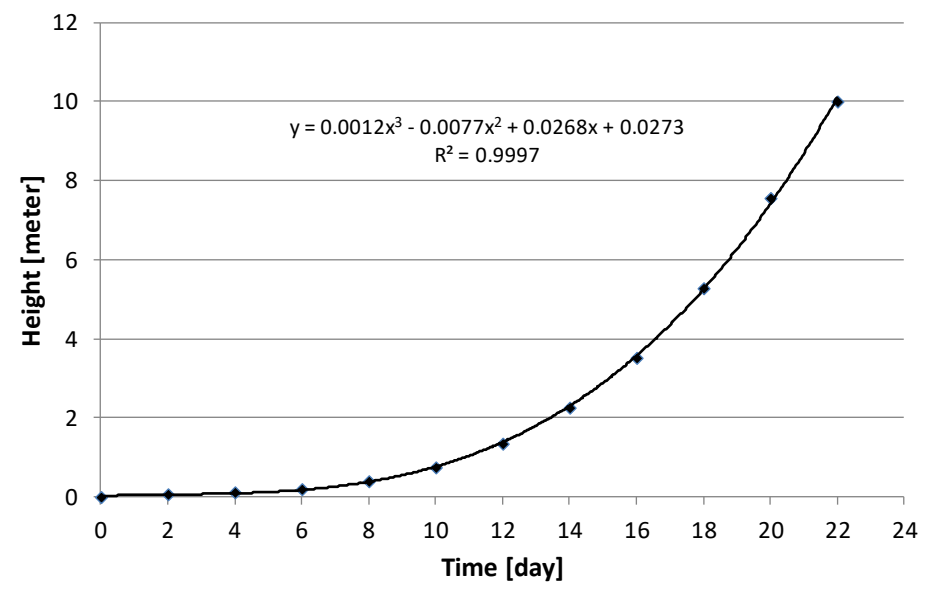

Figure 1. Dynamic of bamboo growth. Source: own elaboration based on [19].

Bamboo growth dynamics are very interesting, as the plant is characterized by fast longitudinal growth within the second and third weeks. In its first growth phase (i.e., the first 12 days), daily length increase has been estimated up to $6 \mathrm{~cm}$; after that, growth dynamics increase rapidly and during the next 4 days bamboo grows $37 \mathrm{~cm}$. During the third week, bamboo can grow up to $80 \mathrm{~cm}$ per day. Due to these properties, bamboo absorbs large amounts of $\mathrm{CO}_{2}$. Simulations conducted on bamboo cultivation show that if 10 million hectares of additional bamboo were planted in a total of 30 years, bamboo plants and products could save over 7 gigatons of $\mathrm{CO}_{2}$ [19].

\subsection{Current Bamboo Applications}

Bamboo has been known and used for different applications since ancient times, but it has largely been forgotten for decades in the past. Nowadays, however, the benefits of bamboo have been revisited and argued for scientifically once again. Bamboo has become widely used for a broad range of purposes after the intensification of research on it during the 1980s, which significantly contributed to understanding the importance of woody grasses and thus to an increase in and improvement of bamboo processing for wider use [20]. Although several solutions have been implemented and scientific papers published, bamboo research remains fresh and worth considering. Bamboo research has attracted significant interest; available studies include a wide variety of topics from bamboo's anatomy [21] through its use in products of daily life, in building, or for the fabrication of musical instruments [22,23].

The abundance of bamboo as a valuable resource in some regions requires prospects for further research. Its market and the influence of different factors (e.g., trade problems, high fuel costs, currency rate changes) on bamboo production have been described in the past $[24,25]$. In traditional, time-honoured products such as handicrafts, blinds, and bamboo shoots, demand remains strong, with sustained earning potential despite moderate growth 
Other traditional and widely used products such as chopsticks are highly commoditytraded and have commercial value but low growth and profit margins.

Young bamboo shoots contain up to $90 \%$ water and are rich in vitamins, cellulose, and amino acids. Bamboo contains from 2-6\% starch, $2 \%$ deoxidized saccharide, $2-4 \%$ fat, and $0.8-6 \%$ protein. It has also been reported to have a high nutritional value, low fat content, and as being rich in valuable fibre. Bamboo shoots are sold fresh in bazaars and markets and are exported all over the world preserved in brine, representing a multimillion-dollar trade commodity [26]. Because of its numerous varieties, which also allow for the acquisition of material with different properties, bamboo has potential as a bioenergy crop, but also as a material for niche markets. Despite some studies in which the high yield of bamboo seems exaggerated, bamboo is still not widely discussed in terms of productivity and industrial applications; most reports have come from Asia in the last 15-20 years, where bamboo has expanded as a superior substitute for wood. The significant role of bamboo in industrial production and environmental protection, however, requires more comprehensive research and statistics on bamboo resources, as well as an estimation of its use in international trade [27]. This lack of information is identified as a significant knowledge gap worth attention.

\subsection{Bamboo for Environmental Protection}

Bamboo grows very easy in different climate conditions and altitudes [28], which allows it to help to increase forest resource volumes [29] and reduce the pressure of timber consumption from natural forests as substitute products for wood [30,31]. Bamboo forests possess great potential for carbon sequestration, and they are the most likely type of forest to enter the emission reduction market [32]. Several studies have reported the role of bamboo forests in global carbon cycling $[19,33]$ as well as their successful use in absorbing wastewater from agriculture, industry, animal husbandry, and pollution. Bamboo is particularly useful in terms of air protection as a good material for carbon sequestration. The $\mathrm{CO}_{2}$-absorbing properties of bamboo have been studied in the past mainly in areas where bamboo naturally forms wild forests. Bamboo forests play a leading role in regional and global carbon (C) cycles and carbon sink [34,35]. Bamboo can absorb up to 12 tons of $\mathrm{CO}_{2}$ per hectare per year, stabilizing the gas content in the atmosphere and releasing 30\% more oxygen than other plants [36]. Therefore, bamboo can be considered as reducing negative effects of climate change as a large carbon sink in nature, playing a key role in adapting and improving human ecosystems.

Figure 2 shows bamboo forests in Batumi (Georgia), which absorb carbon dioxide from the atmosphere and thereby contribute to the improvement of the air condition.

These estimates suggest that growing bamboo on 10 million hectares is equivalent to saving primary energy consumption for more than 300 million new electric cars. This statistic does not include the emissions saved by replacing aluminium, concrete, plastic, or steel with bamboo. The replacement of traditional building materials can therefore contribute to a positive environmental and climate change impact.

\subsection{Bamboo as Material in the Construction Sector}

Bamboo is characterized by high strength and flexibility, which makes it an ideal building and construction material in Africa, Asia, and Latin America. Bamboo, because of its microfiber structures containing lignin and hemicellulose (lignin-carbohydrate complex (LCC)), has a greater strength than concrete and steel by weight, and this strength is due to the thickness of the fibre in the sclerenchyma tissue [37]. The tensile strength of bamboo (Table 1) is greater than that of mild steel, and it can withstand compression twice as well as concrete, easily replacing materials stuck in road construction, drainage pipes, housing, and wind turbine construction [28]. The tensile strength of bamboo is $160 \mathrm{~N} / \mathrm{mm}^{2}$, three times stronger than most types of constructional timber used in industry [19]. The compressive strength is $40-80 \mathrm{~N} / \mathrm{mm}^{2}$, two to four times the value of most timber species. Bending strength is $50-150 \mathrm{~N} / \mathrm{mm}^{2}$, twice strong as convectional structural 
timbers. Bamboo material can be used for almost all elements of construction and home furnishing, including poles supporting ceilings or roofs, or as elements of walls and floors. Bamboo may be substituted for wood in many industrial adhibitions and thereupon contribute to the restoration and saving of the world's forests. For example, in architecture, panels and boards made of bamboo are characterized by high hardness and are abrasionresistant; they are also classified as durable materials and able to replace more expensive hardwood products. Bamboo can also be used as beams and trusses. Adding bamboo to cement has been reported as strengthening concrete structures, with great potential for the mass construction of inexpensive dwellings or as an excellent material for building structures with great resiliency to earthquakes and landslides [38].

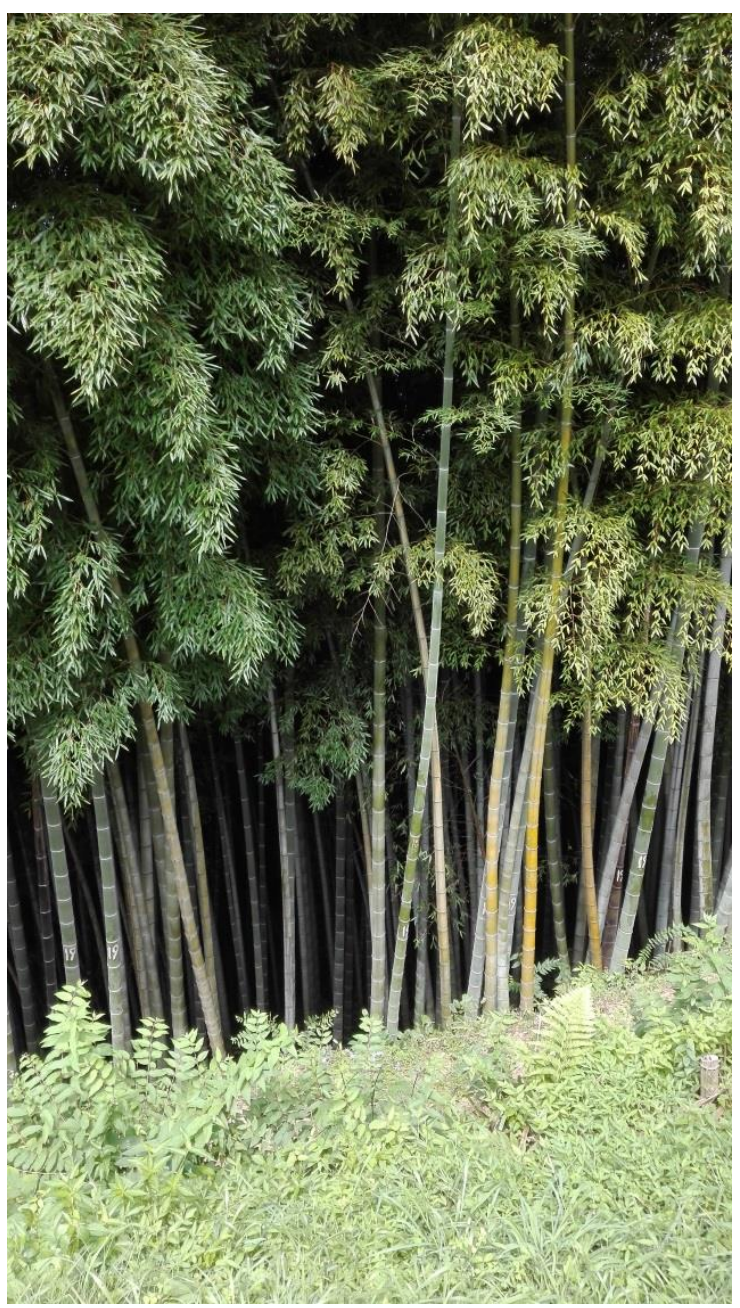

Figure 2. Bamboo (Phyllostachys pubescens Moso Bamboo) forest in Batumi (Georgia, Caucasus).

The construction industry faces major concerns about their associated carbon emissions, which are considered responsible for $7 \%$ of global $\mathrm{CO}_{2}$ emissions. Therefore, the need to explore alternative building materials that will reduce the overall amount of $\mathrm{CO}_{2}$ emissions is a pressing and stimulating research topic on alternative building materials [39]. Solutions that can be considered innovative are more and more often sought. The search for solutions related to alternative materials has turned attention toward bamboo as a reinforcing material. Organic waste (e.g., bamboo leaves or a mixture of straw) can be used, after thermal activation, during cement production and have been identified as a cheap alternative to the production of composites reinforced with natural fibres and as significantly improving the mechanical properties [40]. 
Table 1. Comparison of selected mechanical properties of spruce wood, steel, and bamboo. Source: own elaboration based on [41-44].

\begin{tabular}{cccc}
\hline Properties $\left[\mathbf{k N} / \mathbf{c m}^{2}\right]$ & Spruce Wood & Steel & Bamboo \\
\hline Modulus of elasticity & 1100 & 21,000 & 2000 \\
Modulus of rupture & 7.2 & 20.0 & $12.1-20.9$ \\
Compressive strength & 4.3 & 14.0 & $6.2-9.5$ \\
Tension strength & 8.9 & 16.0 & $14.8-38.4$ \\
Bending strength & 6.8 & 14.0 & $7.6-27.6$ \\
Shear strength & 0.7 & 9.2 & 2.0 \\
\hline
\end{tabular}

The values of the mechanical properties for bamboo presented in Table 1 are given in numerical intervals, because their value depends on the diameter of the culm and the wall thickness of the tested material sample.

Due to the presented properties in the Table 1, bamboo is widely used in construction. Figures 3 and 4 show examples of bamboo serving as a pole supporting the ceiling and elements in strengthening the foundations.

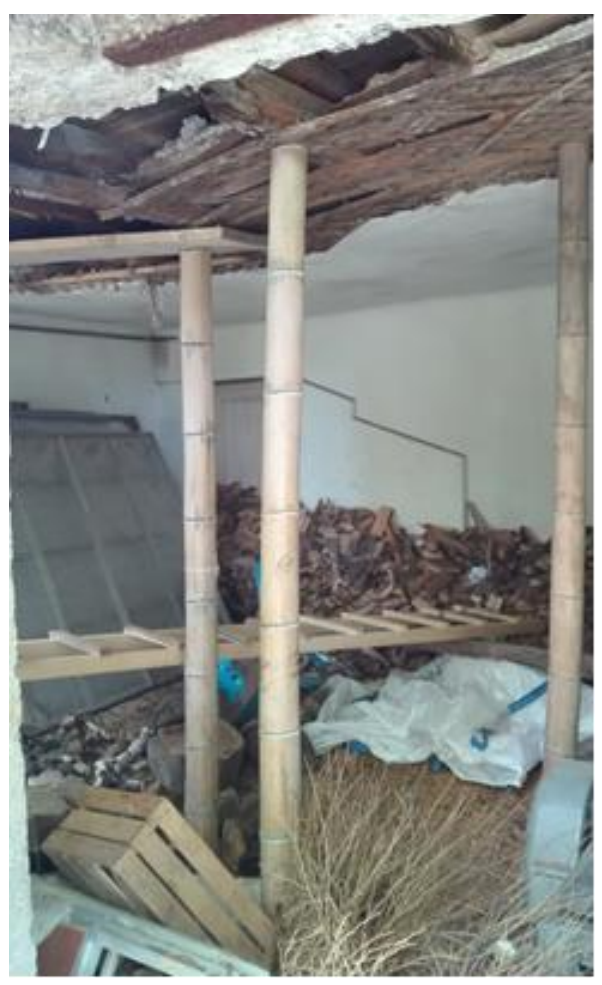

Figure 3. Ceiling support (Batumi 2019).

Burning bamboo produces ash with potential applications in construction. Dry bamboo ash is used as a concrete additive to make cubes, cylinders, and beams. The addition of bamboo ash increases the compression module of concrete cubes, the tensile module of concrete cylinders, and the bending strength module of concrete beams [45]. The addition of bamboo ash improves concrete's strength and shortens setting time, improves consistency, compaction factor, precipitation, and water absorption. Therefore, adding bamboo ash saves construction costs and improves concrete's properties [46].

\subsection{Bamboo for Energy Production}

Bamboo has been suggested as having potential as a bioenergy material. It is characterized by several worthy fuel characteristics with certain other bioenergy substances, such as a low ash content and alkali index. The main components of bamboo culms are 
lignin, cellulose, and hemi-cellulose, amounting for over $90 \%$ of the total mass. The minor constituents of bamboo are resins, tannins, waxes, and inorganic salts. Compared to wood, bamboo has a higher content of alkaline extracts, ash, and silica [30]. The major ash-forming constituents from bamboo are potassium $\left(\mathrm{K}_{2} \mathrm{O}\right)$ and silica $\left(\mathrm{SiO}_{2}\right)$. It also contains chlorine $(\mathrm{Cl})$, calcium $(\mathrm{CaO})$, and magnesium $(\mathrm{MgO})$. To evaluate the quality of biofuels, it is essential to have knowledge of the contents of chlorine $(\mathrm{Cl})$ and sulphur (S). A high amount of these elements provokes corrosion and contamination of boilers, pipes, and guide wires and increases emissions of $\mathrm{SOx}, \mathrm{Cl}_{2}$, and $\mathrm{HCl}$ [47]. Due to its specific chemical composition, bamboo is resistant to attacks from fungi, mould, and borers [48].

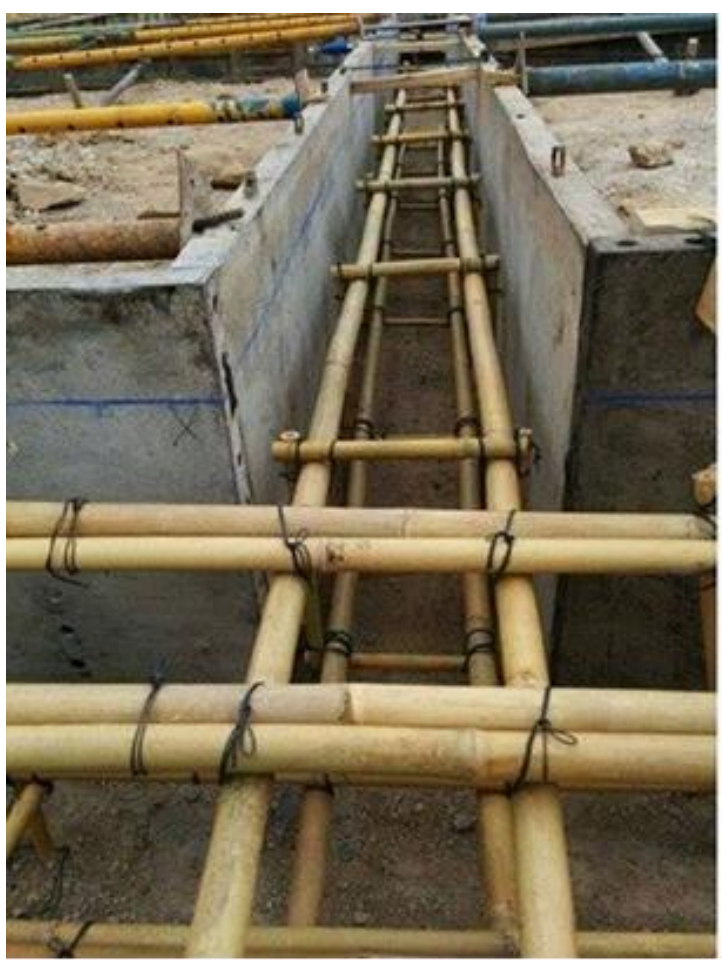

Figure 4. Bamboo in replacement for steel reinforcement.

Because the plant's quality is improved by cutting and harvesting, bamboo can be re-harvested in three-year cycles without any noxious upshot on the environment. If we compare the average length of the lifespan of sequoia, which is about 500 years compared with the lifespan of bamboo, it is easily visible that it is much longer than that of bamboo, so that we can see that bamboo can be harvested and cultivated for over 150 times [47]. Energy produced from bamboo biomass has great potential to become an alternative to traditional fossil fuel. Bamboo biomass is obtained from the entire plant and comes from the stems, the culms, and the branches and leaves. Bamboo biomass can be converted in many ways (e.g., through biochemical or thermal conversion) to produce various energy products (e.g., syngas and biofuels or charcoal) which can become substitutes for subsisting fossil fuel products. Bamboo biomass alone, however, is not able to meet and satisfy global energy demand. It needs to be combined with other sources to best exploit its potential and provide a sustainable energy supply [48]. The research conducted shows that bamboo biomass has a relatively higher calorific value than other sorts of biomass plants, which means that it is a good material for direct combustion (e.g., co-combustion in a thermal power plant). Many different projects concerning bamboo energy are functioning, operating, or being implemented all over the world. In African countries, bamboo biomass projects are very popular, and bamboo there is most likely to be used as a substitute for firewood or charcoal in domestic use. One possible method of converting biomass into biofuel is through the hydrothermal carbonization process, also known as hydrothermal carbonization (HTC). 
However, it should be noted that the calorific value of bamboo is higher than that of most agricultural waste, but lower than that of most wood products. However, the HTC process offers the possibility of increasing the energy density of bamboo using an essentially exothermic and relatively simple process. Bamboo, thanks to its features and properties, is an interesting and suitable material of plant origin to produce biochar [49].

Another possibility for using bamboo biomass is biochar, as mentioned above. Biochar from raw bamboo biomass can be effectively used for securing anionic radioactive pollutants. Positive use of bamboo biochar was noted during its use at elevated concentrations of Tc in the environment, which occurred accidentally during leaks from a nuclear facility. Biochar represents a possibility of $\mathrm{TcO}_{4}{ }^{-}$separation [50]. Currently, research is also being carried out on biocarbon, which, using natural additives, is a promising tool for immobilizing and neutralizing various pollutants in liquid waste, water solutions, and soils. By using bamboo as a biomass raw material, the sorption properties can be further improved. Biochar with the addition of bamboo biomass was produced and synthesized as a biochar/montmorillonite composite in an experimental pyrolysis reactor. The bamboobased biochar/montmorillonite composite can be effectively used in sewage treatment plants where the treatment of industrial wastewater or wastewater-containing anionic pollutants, such as nitrates, is carried out [51].

\subsection{Bamboo as an Additive for Biodegradable Products}

Research conducted with biodegradable materials suggests that the addition of substrates (e.g., bamboo, pine dust) changes the mechanical and chemical properties of biodegradable materials [52]. Bamboo is fast replacing plastic and other production materials. For example, plates and cups are produced from bamboo-plastic composites, popularly known as BPCs. BPCs consist of bamboo fibres mixed with epoxy resins which are biodegradable depending on the type of polymers and other chemicals used in their production [53]. Bamboo additives have been also used for packaging films for food. Biocomposite films are prepared using bamboo fibre to reinforce other modified and unmodified natural materials, resulting in improved mechanical characteristics. Experimental results have demonstrated the high potential of renewable and biodegradable biopolymer composite films in the food industry [54]. Biocomposite samples have been technologically reinforced with raw bamboo fibre and then processed, showing increased biodegradability and weight reduction after 30 days of analyses. Generally, the biodegradability studies have indicated that crude bamboo fibre in biocomposites strengthened the activity and effects of microorganisms due to the higher lignin and hemicellulose contents [55].

Furthermore, bamboo products have adequate hydrophilicity and permeability. Bamboo-related textile products are characterized by a soft touch, excellent colour, and antibacterial and anti-allergic properties. Other important features are that bamboo fibre is UV protective, biodegradable, naturally anti-bacterial, breathable cool, strong flexible, soft, and of a luxurious shiny appearance [56]. Bamboo fibre, thanks to its properties, very quickly and effectively absorbs and facilitates the evaporation of sweat and moisture. Its ultimate respiration ability keeps the exploiter convenient and dry for a much longer period. For creators in the textile industry belonging to a creative industry, bamboo material is perfect for creating new designs that meet fashion expectations. Figure 5 shows bamboo textile products. Due to its properties, bamboo can be used as excellent textile material.

\subsection{Bamboo in Gardening and Architecture}

Bamboo is an excellent material for the construction of different elements and structures in gardens and zoos, as shown at the Figures 6 and 7 respectively.

The main advantages of using bamboo in zoos include sourcing rapidly renewable products, easy replacement during construction or reconstruction of new animal exhibits, and also the provision of a sense of security to animals and help in protecting wildlife habitat. The use of sustainable building materials like bamboo reduces negative environmental impacts such as the deforestation of green areas and other negative and/or 
destructive practices. Several bamboo products, including sanitary sticks, bamboo brooms, and bamboo fans, have become a daily need for a wide range of people [57]. Bamboo timbers are luxury woody materials widely used in furniture and flooring [11]; they are also the most suitable materials for building development and bridge construction due to their microstructural and mechanical strength [58].

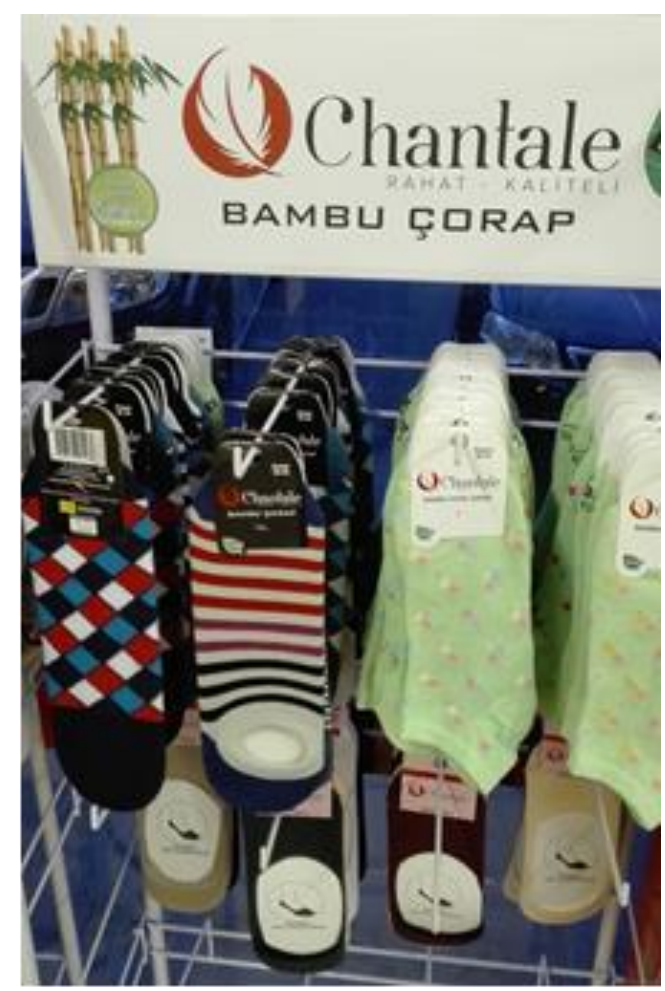

Figure 5. Bamboo socks in a Turkish shop (Artvin 2019).

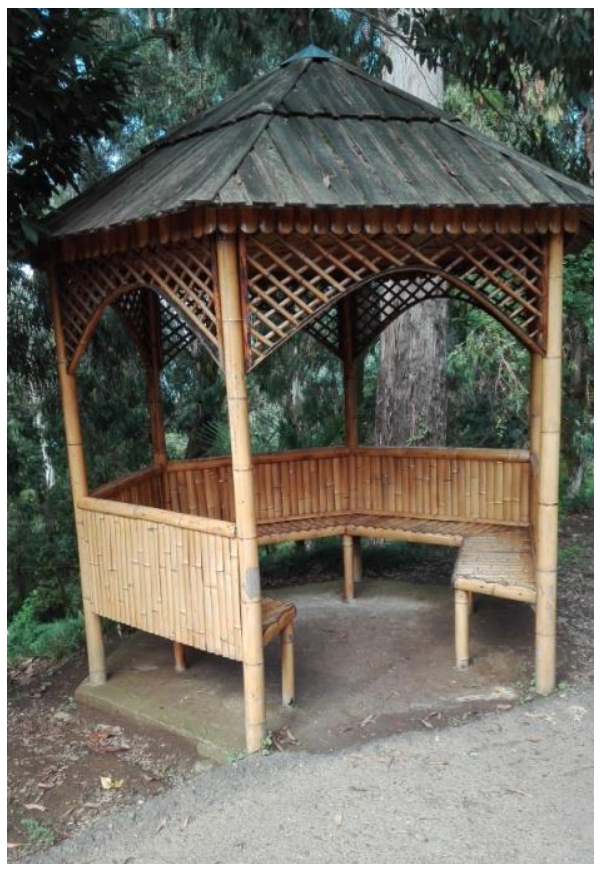

Figure 6. Bamboo gazebo in a garden in Batumi (2019). 


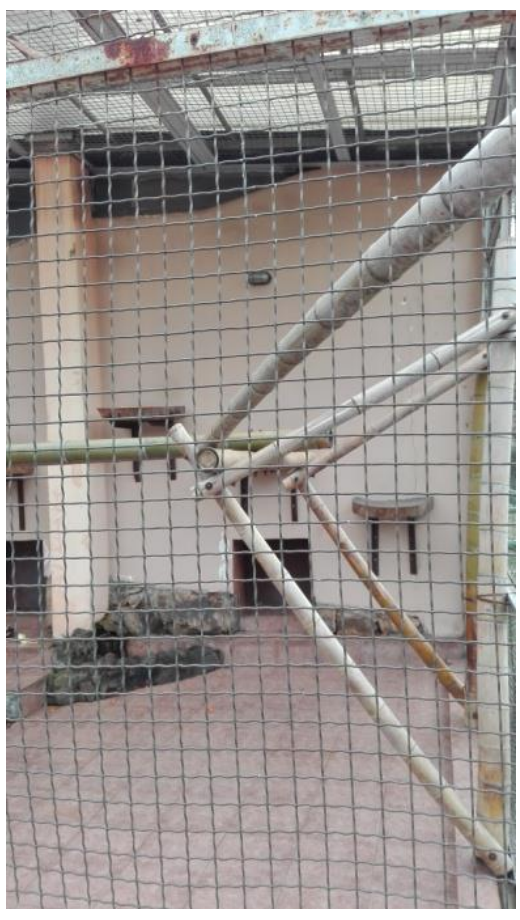

Figure 7. Bamboo elements in enclosure for animals (Batumi 2019).

\section{Conclusions}

In Europe and around the world, cultivation of and, above all, use of bamboo in production can achieve a high level of innovation and creativity. Because of its renewable properties and as a low-carbon substitute for plastic and paper, bamboo can be a perfect alternative to timely single-use goods. However, by using bamboo, we can achieve much more, such as substituting emissions-intensive materials (e.g., steel, cement, and PVC) in a broad scope of durable products. A Europe of high-vignetted Member States today is witnessing several technological advances in some areas of the economy and industry, such as micro-propagation, the selection of superior genotypes using molecular markers, and biomass gasification for energy production and environmental protection. Any bamboo product used on a large scale, and especially on an industrial scale, means that it will be used throughout the economy, especially in the construction [59-61], textile, and food industries. Bamboo can be used not only as an advanced sustainable material for engineering purposes, but also as an advanced material in the substitute food industry such as bamboo fibre for better texture performance. For a short time, from the micro-scale point of view, bamboo can be produced and used in a broadly understood natural environment, e.g., in gardening (as small sticks to support flowers and plants, vine poles, or fruit trees), architectural arches [51], agriculture (in soil stabilization, floodplain improvement), or wind protection (arbours or even as the trees themselves). Two values seem to be significant for the use of bamboo, namely: the determination of the calorific value in the processes of gasification and of defibrillation in the production of biodegradable plates or materials.

\section{Recommendation}

Because of its properties, bamboo is suggested as a material for use in many economic sectors. Thoroughly examining bamboo's possibilities as an additive to biocomposites and checking the properties of the biomass used as material in power plants is an interesting pending task. At this point, attention should be paid to bamboo ash, including its melting temperature and physico-chemical composition, as key parameters in the combustion process. Dry bamboo ash can be used as an additive substation for cement production to improve the properties of concrete. In addition, bamboo can be used in the food industry 
and in medicine. It is therefore worthwhile for further research to analyse bamboo's additional possibilities.

Author Contributions: Conceptualization, P.F.B.; methodology, P.F.B.; validation, I.P. and E.R.B.; formal analysis, P.F.B.; investigation, P.F.B.; resources, P.F.B. and E.R.B.; writing-original draft preparation, P.F.B. and I.P.; writing-review and editing, P.F.B. and E.R.B.; visualization, P.F.B.; supervision, I.P. and E.R.B. All authors have read and agreed to the published version of the manuscript.

Funding: This research received no external funding.

Institutional Review Board Statement: Not applicable.

Informed Consent Statement: Not applicable.

Data Availability Statement: Data sharing is not applicable to this article.

Conflicts of Interest: The authors declare no conflict of interest.

\section{References}

1. Borowski, P.F. Innovation strategy on the example of companies using bamboo. J. Innov. Entrep. 2021, 10, 3. [CrossRef] [PubMed]

2. Müller, J.M.; Buliga, O.; Voigt, K.I. Fortune favors the prepared: How SMEs approach business model innovations in Industry 4.0. Technol. Forecast. Soc. Chang. 2018, 132, 2-17. [CrossRef]

3. Winn, M.I.; Pogutz, S. Business, Ecosystems, and Biodiversity: New Horizons for Management Research. Organ. Environ. 2013, 26, 203-229. [CrossRef]

4. Hu, D.; Wang, Y.; Yang, X. Trading Your Diversification Strategy for a Green One: How Do Firms in Emerging Economies Get on the Green Train? Organ. Environ. 2019, 32, 391-415. [CrossRef]

5. Javadian, A.; Smith, I.F.C.; Saeidi, N.; Hebel, D.E. Mechanical Properties of Bamboo through Measurement of Culm Physical Properties for Composite Fabrication of Structural Concrete Reinforcement. Front. Mater. 2019, 6, 1-18. [CrossRef]

6. Shen, L.; Yang, J.; Zhang, R.; Shao, C.; Song, X. The benefits and barriers for promoting bamboo as a green building material in China-An integrative analysis. Sustainability 2019, 11, 2493. [CrossRef]

7. Chaowana, K.; Wisadsatorn, S.; Chaowana, P. Bamboo as a Sustainable Building Material—Culm Characteristics and Properties. Sustainability 2021, 13, 7376. [CrossRef]

8. Bąkowska, K.; Marczewski, K.; Sawulski, J.; Sztolsztejner, A. Rola Gospodarki Kreatywnej w Polsce; Polski Instytut Ekonomiczny: Warsaw, Poland, 2020.

9. Wu, S.H.; Fan, K.K. Sustainable development of traditional bamboo ferniture in Taiwan: A study on design style. J. Sci. Des. 2021, 5,2_51-2_60. [CrossRef]

10. Rao, F.; Ji, Y.; Li, N.; Zhang, Y.; Chen, Y.; Yu, W. Outdoor bamboo-fiber-reinforced composite: Influence of resin content on water resistance and mechanical properties. Constr. Build. Mater. 2020, 261, 120022. [CrossRef]

11. Emamverdian, A.; Ding, Y.; Ranaei, F.; Ahmad, Z. Application of Bamboo Plants in Nine Aspects. Sci. World J. 2020, $2020,7284203$. [CrossRef]

12. Zhang, H.; Zhong, J.; Liu, Z.; Mai, J.; Liu, H.; Mai, X. Dyed bamboo composite materials with excellent anti-microbial corrosion. Adv. Compos. Hybrid Mater. 2021, 4, 294-305. [CrossRef]

13. Colombo, L.A.; Pansera, M.; Owen, R. The discourse of eco-innovation in the European Union: An analysis of the Eco-Innovation Action Plan and Horizon 2020. J. Clean. Prod. 2019, 214, 653-665. [CrossRef]

14. Kumar, A.; Behura, A.K.; Rajak, D.K.; Behera, A.; Kumar, P.; Kumar, R. Fundamental Concepts of Bamboo: Classifications, Properties and Applications. Bamboo Fiber Compos. 2021, 39-62.

15. Gui, Y.; Wang, S.; Quan, L.; Zhou, C.; Long, S.; Zheng, H.; Jin, L.; Zhang, X.; Ma, N.; Fan, L. Genome size and sequence composition of moso bamboo: A comparative study. Sci. China Ser. C 2007, 50, 700-705. [CrossRef] [PubMed]

16. Shao, Z.; Huang, S.; Wu, F.; Zhou, L.; Clement, A. A study on the difference of structure and strength between internodes and nodes of bamboo. J. Bamboo Res. 2008, 27, 48-52.

17. Chung, M.J.; Wang, S.Y. Physical and mechanical properties of composites made from bamboo and woody wastes in Taiwan. J. Wood Sci. 2019, 65, 1-10. [CrossRef]

18. Tamang, D.K.; Dhakal, D.; Shrestha, D.G. Bamboo resources of Sikkim Himalaya: Diversity, distribution and utilization. J. For. Res. 2014, 25, 929-934. [CrossRef]

19. Borowski, P. Bamboo as an innovative material for many branches of world industry. Ann. WULS SGGW For. Wood Technol. 2019, 107, 13-18. [CrossRef]

20. Liese, W. Research on bamboo. Wood Sci. Technol. 1987, 21, 189-209.

21. Grosser, D.; Liese, W. On the anatomy of Asian bamboos, with special reference to their vascular bundles. Wood Sci. Technol. 1971, 5, 290-312. [CrossRef]

22. Bucur, V. Traditional and new materials for the reeds of woodwind musical instruments. Wood Sci. Technol. 2019, 53, 1157-1187. [CrossRef] 
23. Dixon, P.G.; Gibson, L.J. The structure and mechanics of Moso bamboo material. J. R. Soc. Interface 2014, 11, 20140321. [CrossRef] [PubMed]

24. Marsh, J.; Smith, N. New Bamboo Industries and Pro Poor Impacts: Lesions from China and Potential for Mekong Countries. 2012. Available online: http://www.fao.org/docrep/010/ag131e/ag/131e25.htm (accessed on 6 January 2022).

25. Atanda, J. Environmental impacts of bamboo as a substitute constructional material in Nigeria. Case Stud. Constr. Mater. 2015, 3, 33-39. [CrossRef]

26. Dai, Y.; Hwang, S.-H. Technique, Creativity, and Sustainability of Bamboo Craft Courses: Teaching Educational Practices for Sustainable Development. Sustainability 2019, 11, 2487. [CrossRef]

27. Lobovikov, M.; Paudel, S.; Piazza, M.; Ren, H.; Wu, J. World Bamboo Resources-A Thematic Study Prepared in the Framework of the Global Forest Resources Assessment 2005; Food and Agricultural Organization of the United Nations: Rome, Italy, $2007 ;$ p. 33.

28. Canavan, S.; Richardson, D.M.; Visser, V.; Le Roux, J.J.; Vorontsova, M.S.; Wilson, J.R. The global distribution of bamboos: Assessing correlates of introduction and invasion. AoB Plants 2017, 9, plw078. [CrossRef]

29. Du, H.; Mao, F.; Li, X.; Zhou, G.; Xu, X.; Han, N.; Sun, S.; Gao, G.; Cui, L.; Li, Y.; et al. Mapping global bamboo forest distribution using multisource remote sensing data. IEEE J. Sel. Top. Appl. Earth Obs. Remote Sens. 2018, 11, 1458-1471. [CrossRef]

30. Liu, W.; Hui, C.; Wang, F.; Wang, M.; Liu, G. Review of the resources and utilization of bamboo in China. Bamboo Curr. Future Prospects 2018, 133-142.

31. Terefe, R.; Jian, L.; Kunyong, Y. Role of bamboo forest for mitigation and adaptation to climate change challenges in China. J. Sci. Res. Rep. 2019, 24, 1-7. [CrossRef]

32. Yasin, I.; Priyanto, A. Analysis of bamboo mechanical properties as construction eco-friendly materials to minimizing global warming effect. IOP Conf. Ser. Mater. Sci. Eng. 2019, 535, 012001. [CrossRef]

33. Kang, F.; Li, X.; Du, H.; Mao, F.; Zhou, G.; Xu, Y.; Huang, Z.; Ji, J.; Wang, J. Spatiotemporal Evolution of the Carbon Fluxes from Bamboo Forests and their Response to Climate Change Based on a BEPS Model in China. Remote Sens. 2022, 14, 366. [CrossRef]

34. Guo, Z.; Hu, H.; Li, P.; Li, N.; Fang, J. Spatio-temporal changes in biomass carbon sinks in China's forests from 1977 to 2008. Sci. China Life Sci. 2013, 56, 661-671. [CrossRef] [PubMed]

35. Xu, B.; Guo, Z.; Piao, S.; Fang, J. Biomass carbon stocks in China's forests between 2000 and 2050: A prediction based on forest biomass-age relationships. Sci. China Life Sci. 2010, 53, 776-783. [CrossRef] [PubMed]

36. Laidler, K. The Bear's Necessity. 2003. Available online: https://www.theguardian.com/environment/2003/mar/20/research science (accessed on 6 January 2022).

37. Available online: https://bamcore.com/wp-content/uploads/2019/01/Carbon-Farming-with-Timber-Bamboo.pdf (accessed on 6 January 2022).

38. Ban, Y.; Zhi, W.; Fei, M.; Liu, W.; Yu, D.; Fu, T.; Qiu, R. Preparation and Performance of Cement Mortar Reinforced by Modified Bamboo Fibers. Polymers 2020, 12, 2650. [CrossRef] [PubMed]

39. Shu, B.; Xiao, Z.; Hong, L.; Zhang, S.; Li, C.; Fu, N.; Lu, X. Review on the application of bamboo-based materials in construction engineering. J. Renew. Mater. 2020, 8, 1215-1242.

40. Mahamat, A.; Bih, N.L.; Ayeni, O.; Onwualu, P.A.; Savastano, H., Jr.; Soboyejo, W.O. Development of Sustainable and Eco-Friendly Materials from Termite Hill Soil Stabilized with Cement for Low-Cost Housing in Chad. Buildings 2021, 11, 86. [CrossRef]

41. Frías-Rojas, M.; Sánchez-de-Rojas-Gómez, M.I.; Medina-Martínez, C.; Villar-Cociña, E. New Trends for Nonconventional CementBased Materials: Industrial and Agricultural Waste. In Sustainable and Nonconventional Construction Materials Using Inorganic Bonded Fiber Composites; Woodhead Publishing: Sawston, UK, 2017; pp. 165-183.

42. Gutu, T.A. Study on the mechanical strength properties of bamboo to enhance its diversification on its utilization. Int. J. Innov. Technol. Explor. Eng. 2013, 2, 314-319.

43. Available online: https://www.azom.com/properties.aspx?ArticleID=965 (accessed on 6 January 2022).

44. Mousavi, S.R.; Zamani, M.H.; Estaji, S.; Tayouri, M.I.; Arjmand, M.; Jafari, S.H.; Nouranian, S.; Khonakdar, H.A. Mechanical properties of bamboo fiber-reinforced polymer composites: A review of recent case studies. J. Mater. Sci. 2022, 57, $3143-3167$. [CrossRef]

45. Available online: https://www.fpl.fs.fed.us/documnts/fplgtr/fplgtr113/ch04.pdf (accessed on 6 January 2022).

46. Chandrasekaran, V. Characteristics investigations of dry bamboo ash fractional replaced cement with in M25 grade concrete. Ann. Chim. Sci. Matér. 2021, 45, 153-159. [CrossRef]

47. Onikeku, O.; Shitote, S.M.; Mwero, J.; Adedeji, A. Evaluation of characteristics of concrete mixed with bamboo leaf ash. Open Constr. Build. Technol. J. 2019, 13, 67-80. [CrossRef]

48. Li, Z.; Chen, C.; Mi, R.; Gan, W.; Dai, J.; Jiao, M.; Xie, H.; Yao, Y.; Xiao, S.; Hu, L. A strong, tough, and scalable structural material from fast-growing bamboo. Adv. Mater. 2020, 32, 1906308. [CrossRef]

49. Le, T.M.A.; Truong, H. Overview of Bamboo Biomass for Energy Production. 2014. Available online: https://EconPapers.repec. org/RePEc:hal:wpaper:halshs-01100209 (accessed on 6 January 2022).

50. Schneider, D.; Escala, M.; Supawittayayothin, K.; Tippayawong, N. Characterization of biochar from hydrothermal carbonization of bamboo. Int. J. Energy Environ. 2011, 2, 647-652.

51. Daňo, M.; Viglašová, E.; Galamboš, M.; Štamberg, K.; Kujan, J. Surface Complexation Models of Pertechnetate on Biochar/Montmorillonite Composite—Batch and Dynamic Sorption Study. Materials 2020, 13, 3108. [CrossRef] [PubMed] 
52. Zhang, X.; Sarmah, A.; Bolan, N.; He, L.; Lin, X.; Che, L.; Tang, C.; Wang, H. Effect of aging process on adsorption of diethyl phthalate in soils amended with bamboo biochar. Chemosphere 2016, 142, 28-34. [CrossRef] [PubMed]

53. Żelaziński, T.; Ekielski, A.; Tulska, E.; Vladut, V.; Durczak, K. Wood Dust Application for Improvement of Selected Properties of Thermoplastic Starch. Inmatech Agric. Eng. 2019, 58, 37-43.

54. Zhao, D.X.; Cai, X.; Shou, G.Z.; Gu, Y.Q.; Wang, P.X. Study on the Preparation of Bamboo Plastic Composite Intend for Additive Manufacturing. In Key Engineering Materials; Wang, G., Wang, H., Zhang, X., Li, Y., Li, C., Li, Y., Eds.; Trans Tech Publications Ltd.: Freienbach, Switzerland, 2016; Volume 667, pp. 250-258.

55. Khalil, H.A.; Mohamad, H.C.C.; Khairunnisa, A.R.; Owolabi, F.A.T.; Asniza, M.; Rizal, S.; Fazita, M.R.N.; Paridah, M.T.; Mustapha, A.; Tahir, P.M. Development and characterization of bamboo fiber reinforced biopolymer films. Mater. Res. Express 2018, 5, 085309. [CrossRef]

56. Junior, A.E.C.; Baretto, A.C.H.; Rossa, D.S.; Maia, F.J.N.; Lomanaco, D.; Mazzetto, S.E. Thermal and mechanical properties of biocomposites based on a cashew nut shell liquid matrix reinforced with bamboo fibers. J. Compos. Mater. 2015, 49, 2203-2215. [CrossRef]

57. Devi, S.Y.; Indran, S.; Divya, D. Futuristic Prospects of Bamboo Fiber in Textile and Apparel Industries: Fabrication and Characterization. In Bamboo Fiber Composites; Jawaid, M., Mavinkere Rangappa, S., Siengchin, S., Eds.; Springer: Singapore, 2021; pp. 189-213.

58. Xiao, Y.; Zhou, Q.; Shan, B. Design and construction of modern bamboo bridges. J. Bridge Eng. 2010, 15, 533-541. [CrossRef]

59. Okokpujie, I.P.; Akinlabi, E.T.; Fayomi, O.O. Assessing the policy issues relating to the use of bamboo in the construction industry in Nigeria. Heliyon 2020, 6, e04042. [CrossRef]

60. Tahmasebinia, F.; Ma, Y.; Joshua, K.; Sepasgozar, S.; Yu, Y.; Li, J.; Sepasgozar, S.; Marroquin, F. Sustainable Architecture Creating Arches Using a Bamboo Grid Shell Structure: Numerical Analysis and Design. Sustainability 2021, 13, 2598. [CrossRef]

61. Bui, Q.-B.; Grillet, A.-C.; Tran, H.-D. A bamboo treatment procedure: Effects on the durability and mechanical performance. Sustainability 2017, 9, 1444. [CrossRef] 